\title{
Downstream gene flow and genetic structure of Gambusia holbrooki (eastern mosquitofish) populations
}

\author{
JOSE D. HERNANDEZ-MARTICH* \& MICHAEL H. SMITH \\ Savannah River Ecology Laboratory, Drawer E, Aiken, SC 28902 and Institute of Ecology, University of Georgia, \\ Athens, GA 30602, U.S.A.
}

\begin{abstract}
Twelve populations of Gambusia holbrooki were sampled in three drainages of Florida and southern Georgia and their genetic structure was determined from the electrophoretic variation of 13 loci. There was less genetic variation $(\bar{H}=0.199$ vs. 0.242$)$ and more differentiation within $(\bar{D}=0.108$ vs. 0.097$)$ and among $(\bar{D}=0.192$ vs. 0.148$)$ drainages in upstream than in downstream populations. Estimated levels of gene flow were lower $(\overline{\mathrm{Nm}}=1.2$ vs. 2.5$)$ among upstream than among downstream populations. Florida populations were genetically differentiated from those in Georgia $(\bar{D}=0.184)$. This differentiation could result from the isolation of peninsular Florida and downstream gene flow after it rejoined the mainland.
\end{abstract}

Keywords: allozymes, biogeography, Gambusia holbrooki, gene flow, genetic differentiation, heterozygosity.

\section{Introduction}

Understanding the role of gene flow in evolution requires knowledge of its level and pattern. High levels of gene flow among populations swamp the effects of drift and selection, whereas intermediate levels spread new gene combinations created by drift and selection (Wright, 1988). The pattern of gene flow of riverine fishes is constrained by land, the complexity of the stream order, their level of tolerance to the salt concentration of sea water, other physical barriers to their dispersal, the energetic cost of maintaining place and of swimming against water flow, and the ability of an individual to disperse and leave descendants that will breed in a population other than the one into which it was born. The dispersal ability of fishes also affects their levels of gene flow. Indirect and direct methods for estimating the level of gene flow and their advantages and disadvantages are discussed by Slatkin (1985). Some indirect methods use the geographical variation of allele frequencies.

Geographical variation of genetic characteristics has been documented for natural populations of Gambusia holbrooki in several drainages. They show

\footnotetext{
${ }^{*}$ Correspondence. E-mail: dhrnand@arches.cc.uga.edu
}

more divergence within and between drainages and fewer alleles in the piedmont than in the coastal plain. Piedmont populations also have lower heterozygosity than those in the coastal plain, except in the Savannah River, Ogeechee and Altamaha drainages of Georgia, presumably because introgression with $G$. affinis increases the levels of genetic variation in the piedmont (Fig. 1a). This species occurs in drainages that run to the Gulf of Mexico and in some piedmont locations of the Atlantic coast drainages (Scribner \& Avise, 1993; Hernandez-Martich et al., 1995).

The occurrence of these patterns has been explained as a result of a much higher level of gene flow in the downstream than in the upstream direction. Water flow can produce such patterns by easing downstream dispersal and opposing upstream dispersal (Hernandez-Martich et al., 1995). Water flow rate slows from the upstream reaches to the mouths of rivers (Wooton, 1990). The water velocity and, consequently, downstream gene flow are increased at dams and at the fall line, a high steep boundary with rapids between the piedmont and the coastal plain. The patterns could also result from selection owing to environmental differences between the piedmont and the coastal plain. Another factor that may be involved in creating the 
patterns is genetic drift. Piedmont populations are usually smaller and more isolated than those in the coastal plain. These conditions are more favourable for drift to occur. These three hypotheses are not mutually exclusive, and unidirectional gene flow, selection and drift could cause the geographical patterns of genetic structure (Smith et al., 1983; Hernandez-Martich \& Smith, 1990).

Drainages of southern Georgia and Florida do not originate in the piedmont (Fig. 1a). Thus, they do not have populations affected either by environmental regimes typical of the piedmont or by the barrier effects of the fall line. Furthermore, these drainages do not have major dams. In this study, the genetic structure of $G$. holbrooki in the Satilla, Suwannee and St John's drainages of southern Georgia and Florida is described. In addition, gene flow levels among populations of these and other drainages of Georgia and the Carolinas are inferred.
The main objective was to determine whether, without the fall line, dams and the differences in environmental regimes intrinsic to the piedmont/ coastal plain dichotomy, the species exhibits genetic patterns similar to those in other drainages. Such a finding would support the hypothesis that downstream dispersal plays a major role in shaping the genetic structure of $G$. holbrooki. The occurrence of some divergence between the Georgia and Florida samples is also reported and this divergence is interpreted as resulting from pre-Pleistocene and Pleistocene isolation and dispersal events.

\section{Materials and methods}

In August 1994, mosquitofish were sampled in two upstream and two downstream locations from each of the Satilla, Suwannee and St John's drainages (Fig. 1a). Thirty-six whole fish from each location

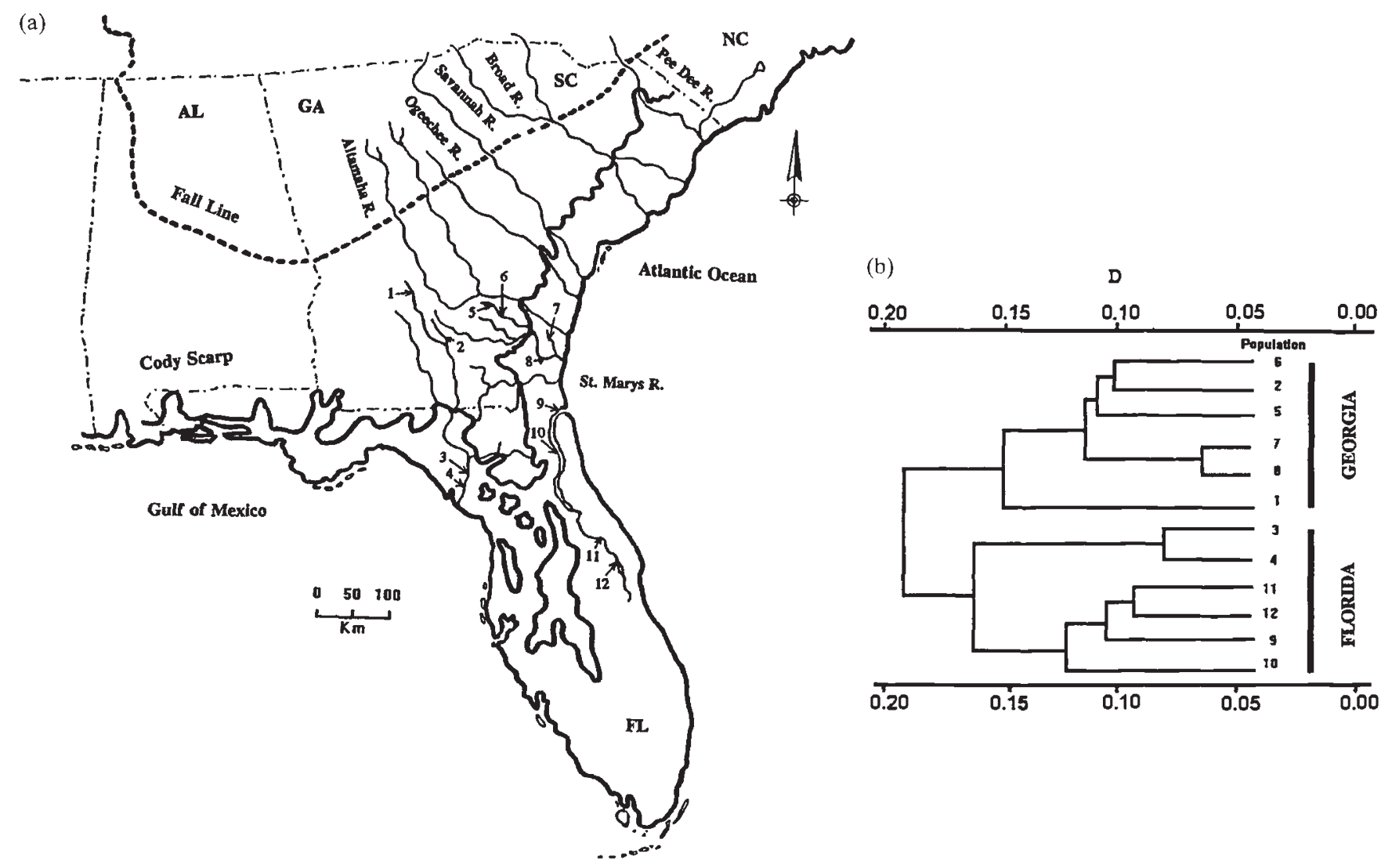

Fig. 1 (a) Upstream and downstream locations (above and below the Cody Scarp, respectively) where mosquitofish were sampled in the Suwannee (1-4), Satilla (5-8) and St John's (9-12) drainages. The regions above and below the fall line are piedmont and coastal plain, respectively. (b) Phenogram based on the Rogers's genetic distance $(D)$ among the sampled populations (cophenetic correlation coefficient was 0.75 ). 
were electrophoresed and scored for adenosine deaminase ( $A D A-1$ *; EC 3.5.4.4), isocitrate dehydrogenase $\left(m I D H-A^{*}\right.$ and $s I D H-A^{*}$; EC 1.1.1.42), L-lactate dehydrogenase ( $L D H-B^{*}$; EC 1.1.1.27), purine-nucleoside phosphorylase (PNP-1*; EC 2.4.2.1) and dipeptidase (PEP- $A^{*}$ - leucyl alanine substrate; EC 3.4.-.-) using a Tris-citrate-EDTA ( $\mathrm{pH}$ 7.0) buffer, and aspartate aminotransferase $\left(m A A T-A^{*}\right.$ and $s A A T-A^{*}$; EC 2.6.1.1), glucose6-phosphate isomerase (GPI- $A^{*}$ and $G P I-B^{*}$; EC 5.3.1.9), malate dehydrogenase ( $m M D H-A^{*}$; EC 1.1.1.37), mannose-6-phosphate isomerase (MPI- $A^{*}$; EC 5.3.1.8) and phosphoglucomutase (PGM-3*; EC 5.4.2.2) using a Tris-citrate ( $\mathrm{pH} \mathrm{8.0)} \mathrm{buffer.} \mathrm{Sampl-}$ ing, transportation, storage and electrophoretic procedures were as in Hernandez (1988).

BIOSYS-1 (Swofford \& Selander, 1989) was used to estimate the mean number of alleles $(\mathrm{Na})$, proportion of polymorphic loci $(P ; 0.95$ criterion), multilocus heterozygosity ( $H$; direct count), modified Rogers's genetic distance among populations ( $D$; Wright, 1978) and $F$-statistics. To test whether single-locus $F_{\mathrm{IS}}$ and $F_{\mathrm{ST}}$ values were significantly different from 0 , the methods of $\mathrm{Li} \&$ Horvitz (1953) and Workman \& Niswander (1970) were used, respectively. BIOSYs-1 was used to perform hierarchical analyses of genetic variance within and among populations $\left(G_{\mathrm{ST}}\right.$; Nei, 1977) and $\chi^{2}$ goodness-of-fit tests for comparisons of the actual genotypic frequencies at each locus with HardyWeinberg expected frequencies. To test for the multilocus significance of each set of single-locus tests, the sequential Bonferroni procedure was used (Rice, 1989).

Spatial relationships among samples were examined with a phenogram based on $D$ and UPGMA algorithm (Sneath \& Sokal, 1973). The average number of individuals migrating among populations in each generation $(\mathrm{Nm})$ was estimated using $F_{\mathrm{ST}^{-}}$ values (Slatkin, 1985) for upstream and downstream populations of the three drainages and overall. $\mathrm{Nm}$ values were also estimated for populations of the Broad-Pee Dee and Ogeechee-Altamaha basins using data from previous studies (Hernandez, 1988; Hernandez-Martich et al., 1995).

To examine whether there was a relationship of $D$ with geographical distance $(\mathrm{km})$ between sampling sites and of site altitude (m) with $D$ or $H$, the Mantel test was used. This test calculates the correlation between two matrices (Sokal \& Rohlf, 1995). One matrix type included the $D$-values (MTX-D) or all the pairwise differences in $H(\mathrm{MTX}-\mathrm{H})$. The other type had all the pairwise differences in altitude (MTX-A) or the inverse geographical distances between the sampling sites (MTX-GEO1 disallowed and MTX-GEO2 allowed connections between the upstream sections of the Suwannee and Satilla drainages). Geographical matrices allowed connections between the Satilla and St John's drainages along the Atlantic Ocean and between Suwannee and St John's/Satilla along the St Mary's River and the Atlantic Ocean (Fig. 1a).

Two-way analyses of variance (ANOVA) using $N a$, $H$ or $P$ as dependent variables and drainages (Satilla, Suwannee and St John's) and sections (upstream vs. downstream) as classes were performed with sAS (SAS Institute, 1985). The arcsine-square-root transformed values of $H$ and $P$ were used in the analyses. Tests of hypotheses were considered significant if $P \leq 0.05$.

\section{Results}

Genotypic proportions were not significantly different from Hardy-Weinberg expectations. $\bar{F}_{\text {IS }}$ was twice as high for the downstream as for the upstream samples, but it was not significantly different from 0 in either case. $F_{\mathrm{ST}^{-}}$-values were significantly different from 0 (Table 1 ).

A $G_{\mathrm{ST}}$ analysis using drainage, section (upstream vs. downstream) and sample as hierarchical levels indicates that 92.1 per cent of the genetic variation occurs within samples, 2.7 per cent occurs among samples within sections, 3.7 per cent occurs between sections within drainages and 1.5 per cent occurs among drainages. For upstream populations, $\bar{D}$ was 0.192 between drainages and 0.108 within drainages, whereas it was 0.148 between drainages and 0.097 within drainages for downstream populations. Overall, $\bar{D}$ between upstream and downstream populations was 0.166 . The phenogram revealed the occurrence of two sample clusters (Fig. 1b). One cluster includes the Georgia samples (from the Satilla and upstream Suwannee drainages), whereas the other includes the Florida samples (from the St John's and downstream Suwannee drainages). The most common allele of each locus was the same in both clusters, but allele frequencies were significantly different $\left(\chi_{35}^{2}=366.57 ; P=0.00\right)$. The average genetic distance between populations of the two clusters was larger $(\bar{D}=0.184)$ than that within each cluster $(\bar{D}=0.124$ for the Georgia cluster and $\bar{D}=0.140$ for the Florida cluster). This difference was highly significant according to a nonparametric Mantel test equivalent to ANOVA (Sokal \& Rohlf, 1995). This method calculates the correlation of MTX-D and a matrix with elements equal to 1 or 0 at the intersections of populations within and 
Table 1 Single-locus heterozygosity $(h)$ averaged across populations and $F$-statistics for eastern mosquitofish populations in the Satilla, Suwannee and St John's drainages

\begin{tabular}{|c|c|c|c|c|c|c|c|}
\hline \multirow[b]{2}{*}{ Locus } & \multirow[b]{2}{*}{$\bar{h}$} & \multicolumn{2}{|c|}{ Upstream } & \multicolumn{2}{|c|}{ Downstream } & \multicolumn{2}{|c|}{ Overall } \\
\hline & & $F_{\text {IS }}$ & $F_{\mathrm{ST}}$ & $F_{\text {IS }}$ & $F_{\mathrm{ST}}$ & $F_{\text {IS }}$ & $F_{\mathrm{ST}}$ \\
\hline$A D A-1^{*}$ & 0.224 & $0.000 \mathrm{NS}$ & 0.087 & 0.197 & 0.077 & $0.094 \mathrm{NS}$ & 0.083 \\
\hline$m A A T-A^{*}$ & 0.035 & $-0.014 \mathrm{NS}$ & $0.007 \mathrm{NS}$ & 0.509 & 0.046 & 0.430 & 0.052 \\
\hline$s A A T-A^{*}$ & 0.002 & $\dagger$ & $\dagger$ & 0.871 & 0.076 & 0.871 & 0.086 \\
\hline$G P I-A^{*}$ & 0.230 & 0.182 & 0.115 & -0.073 & 0.052 & $0.060 \mathrm{NS}$ & 0.088 \\
\hline$G P I-B^{*}$ & 0.469 & $-0.005 \mathrm{NS}$ & 0.127 & -0.037 & 0.052 & $-0.022 \mathrm{NS}$ & 0.090 \\
\hline$m I D H-A^{*}$ & 0.218 & $-0.058 \mathrm{NS}$ & 0.031 & $0.091 \mathrm{NS}$ & $0.021 \mathrm{NS}$ & $0.027 \mathrm{NS}$ & 0.030 \\
\hline$S I D H-A^{*}$ & 0.242 & $-0.067 \mathrm{NS}$ & 0.221 & $0.001 \mathrm{NS}$ & 0.064 & $-0.027 \mathrm{NS}$ & 0.137 \\
\hline$L D H-B^{*}$ & 0.032 & 0.332 & 0.030 & 0.314 & 0.045 & 0.323 & 0.039 \\
\hline$m M D H-A^{*}$ & 0.341 & $0.123 \mathrm{NS}$ & 0.068 & 0.258 & $0.021 \mathrm{NS}$ & 0.193 & 0.044 \\
\hline$M P I-A^{*}$ & 0.377 & $0.040 \mathrm{NS}$ & 0.108 & $0.093 \mathrm{NS}$ & 0.046 & $0.067 \mathrm{NS}$ & 0.078 \\
\hline$P E P-A^{*}$ & 0.265 & 0.197 & 0.097 & 0.182 & 0.058 & 0.186 & 0.104 \\
\hline$P G M-3^{*}$ & 0.159 & $0.017 \mathrm{NS}$ & 0.033 & $0.088 \mathrm{NS}$ & 0.071 & $0.058 \mathrm{NS}$ & 0.059 \\
\hline$P N P-1^{*}$ & 0.058 & 0.216 & 0.255 & 0.223 & 0.098 & 0.221 & 0.198 \\
\hline Mean & 0.220 & $0.069 \mathrm{NS}$ & 0.116 & $0.135 \mathrm{NS}$ & 0.056 & $0.106 \mathrm{NS}$ & 0.093 \\
\hline
\end{tabular}

NS indicates $F$-values not significantly different from $0(P>0.05)$; all the other values were significant $(P \leqslant 0.05)$. Deviations of $F_{I S}$ and $F_{S T}$ from 0 were tested following Li \& Horvitz (1953) and Workman \& Niswander (1970), respectively.

$\nmid$ Monomorphic.

between clusters, respectively. Genetic variation tends to be higher in the Georgia samples than in the Florida samples (Table 2).

Mantel tests of MTX-D against MTX-GEO1 or MTX-GEO2 were highly significant. However, the Mantel's correlation coefficient was higher for MTX-GEO2 than for MTX-GEO1 ( $r=0.637$ vs. 0.501 ). There was no significant correlation between MTX-A and MTX-H $(r=-0.020)$ or between MTX-A and MTX-D $(r=-0.131)$.

Inferred levels of gene flow were consistently higher for the downstream than for the upstream populations. $N m$ was $<2.0$ for the piedmont populations except those in the Satilla, Suwannee and St John's drainages altogether and in the Ogeechee drainages. $N m$ was $\geq 2.0$ for the downstream populations except in the Ogeechee and Altamaha drainages altogether and the Altamaha alone. Based on the combined data of upstream and downstream populations, $N m$ was $\geq 2.0$ for each of the Pee Dee and Ogeechee drainages alone, and for the Satilla, Suwannee and St John's drainages altogether (Table 3).

All the averages of measures of genetic variation within populations were consistently higher in the downstream than in the upstream populations of each drainage. There were more alleles unique to the downstream than to the upstream populations of the three drainages (11 vs. 7). The Anova showed significantly smaller $\mathrm{Na}$ and $\mathrm{H}$ for the upstream than for the downstream populations, but no significant difference among rivers. $P$ was not significantly different between sections or among rivers (Table 2).

\section{Discussion}

Our samples represent different populations, as shown by the significant $F_{\mathrm{ST}}$. These populations exhibit genetic characteristics similar to those of populations in other drainages. First, mating is random as suggested by the nonsignificant $F_{\text {IS }}$. Secondly, there are more alleles and heterozygosity in downstream than in upstream populations. Thirdly, most of the genetic variance occurs within rather than among populations. Genetic variance among populations occurs mostly among local populations and is less among drainages than between sections within drainages. Finally, divergence within and among drainages is less downstream than upstream (Smith et al., 1989; Hernandez-Martich et al., 1995). Similar patterns have been described for guppies in Trinidad, West Indies (Shaw et al., 1994).

Genetic drift and selection may be significant factors causing the local differentiation and the upstream/downstream dichotomy of genetic characteristics. At high elevations, populations are usually smaller and more isolated than those at low eleva- 
tions. Thus, drift is expected to affect the former more than the latter populations (Hernandez, 1988; Shaw et al., 1994). In the three drainages of this study, however, differences in the degree of isolation and in size are weak between the upstream and downstream populations. Upstream populations do not seem to be as highly isolated as those in the piedmont of other drainages. A 1994 summer flooding facilitated fish dispersal between the upstream sections of Suwannee and Satilla near Ocilla (Irwin Co., GA, U.S.A.). On the other hand, no differences in population size between the upstream and downstream populations of drainages restricted to the coastal plain were observed (J. D. Hernandez, in preparation). Thus, genetic drift effects on the structure of mosquitofish populations of these three drainages do not seem to be as strong as in drainages that extend to the piedmont.

Biotic and abiotic factors vary in upstream and downstream waters (Wooton, 1990). In the BroadPee Dee basin, $H$ is correlated with altitude, which

Table 2 Mean measures of genetic variation at 13 loci for eastern mosquitofish populations from the Satilla, Suwannee and St John's drainages

\begin{tabular}{lclc}
\hline Drainage & $N a$ & $P$ & $H$ \\
\hline Satilla & 2.25 & 86.5 & 0.206 \\
& $(0.078)$ & $(3.14)$ & $(0.021)$ \\
Upstream & 2.20 & 84.6 & 0.194 \\
& $(0.115)$ & $(0.00)$ & $(0.034)$ \\
Downstream & 2.31 & 88.5 & 0.219 \\
& $(0.075)$ & $(3.85)$ & $(0.013)$ \\
Suwannee & 2.29 & 86.5 & 0.236 \\
& $(0.078)$ & $(3.68)$ & $(0.021)$ \\
Upstream & 2.20 & 84.6 & 0.206 \\
& $(0.115)$ & $(7.70)$ & $(0.012)$ \\
Downstream & 2.39 & 88.5 & 0.266 \\
& $(0.075)$ & $(3.85)$ & $(0.026)$ \\
St John's & 2.29 & 92.3 & 0.220 \\
& $(0.078)$ & $(3.14)$ & $(0.021)$ \\
Upstream & 2.20 & 88.5 & 0.199 \\
& $(0.115)$ & $(3.85)$ & $(0.024)$ \\
Downstream & 2.39 & 96.2 & 0.241 \\
& $(0.075)$ & $(3.85)$ & $(0.035)$ \\
Overall & 2.28 & 88.5 & 0.221 \\
& $(0.039)$ & $(1.77)$ & $(0.018)$ \\
Upstream & 2.20 & 85.9 & 0.199 \\
& $(0.051)$ & $(2.36)$ & $(0.011)$ \\
Downstream & 2.36 & 91.0 & 0.242 \\
& $(0.038)$ & $(2.36)$ & $(0.014)$ \\
\hline
\end{tabular}

$\mathrm{Na}$ is the average number of alleles, $P$ is the average percentage polymorphic loci ( 0.95 criterion), and $H$ is the average number of heterozygous loci per individual (direct count) in a population. may be associated with gradients of selective pressures (Hernandez, 1988). However, the altitudes for the sampling sites of this study are only between 1 and $3 \mathrm{~m}$, except the upstream Satilla (46 and $61 \mathrm{~m}$ ) and Suwannee (79 and $82 \mathrm{~m}$ ) drainages. Also, the Mantel test showed no correlation of altitude with $H$ or with $D$. However, selective factors not considered in this study might have significant effects in producing the patterns.

Correlation between geographical and genetic distances is not high, but significant, suggesting a genetic structure more complex than that predicted by an isolation-by-distance model but simpler than that for an island model. Mosquitofish live near the shore in freshwater and estuarine habitats. Thus, their gene flow pattern may be better represented by a stepping-stone model with one dimension. This model assumes that dispersal occurs only between adjacent populations that are linearly distributed as in a river. Differentiation in such a model is larger than in multidimensional models (Crow \& Aoki, 1984). Unidirectional gene flow in a one-dimensional stepping stone would cause more differentiation, lower heterozygosity and fewer alleles in the upstream than in the downstream populations, as we have previously reported for $G$. holbrooki and Shaw et al. (1994) have reported for guppies.

When $\mathrm{Nm}$ was estimated, no selection and an island model of gene flow were assumed (Slatkin, 1985). Under these conditions, $\mathrm{Nm}=1$ is enough to keep the same alleles in all populations, but a larger number is needed to prevent their genetic differentiation (Allendorf, 1983). In a stepping-stone model, $N m=2$ is required to have similar effects to those described for the island model when $N m=1$ (Crow \& Aoki, 1984). $\mathrm{Nm}$ calculated from $F_{\mathrm{ST}}$ is not accurate when selection, drift or both factors affect genetic differentiation. If the intensity of any of these factors did not differ in upstream vs. downstream populations, our $\mathrm{Nm}$ values show that gene flow is relatively less among upstream than among downstream populations either within a single drainage or within and among several drainages.

The spatial distribution of genetic characteristics of $G$. holbrooki is consistent with the hypothesis that gene flow occurs mostly in a downstream direction. Evidence for unidirectional (downstream) gene flow has been reported for $G$. holbrooki introduced to Australia (Congdon, 1995). Mosquitofish can disperse up to $18 \mathrm{~km}$ each year at a rate twice as high in a downstream direction as in an upstream direction (Lynch, 1988). Also, large $\mathrm{Nm}$ values like our estimates may reflect gene flow induced by hist- 
Table 3 Estimated number $(\mathrm{Nm})$ of eastern mosquitofish migrating among populations each generation within three river basins

\begin{tabular}{llcl}
\hline $\begin{array}{l}\text { River basin } \dagger \\
\text { Drainage }\end{array}$ & Upstream & Downstream & Overall \\
\hline Broad-Pee Dee & $0.7(37)$ & $2.3(48)$ & $1.3(5)$ \\
$\quad$ Broad $\ddagger$ & $0.8(30)$ & $3.7(19)$ & $1.1(49)$ \\
Pee Dee§ & $1.2(7)$ & $2.8(29)$ & $2.0(36)$ \\
Ogeechee-Altamaha & $0.8(10)$ & $1.1(21)$ & $0.9(31)$ \\
$\quad$ Ogeechee & $2.2(4)$ & $5.1(6)$ & $2.8(10)$ \\
Altamaha & $0.6(6)$ & $1.0(15)$ & $0.7(21)$ \\
Satilla-Suwannee-St John's & $2.0(6)$ & $4.2(6)$ & $2.4(12)$ \\
\hline
\end{tabular}

Estimates were derived from $F_{\mathrm{ST}}$-values (Wright, 1943) computed from the number of populations in parentheses.

$\dagger N m$ values for Broad, Pee Dee, Ogeechee and Altamaha drainages were calculated using data from Hernandez (1988) and Hernandez-Martich et al. (1995).

$\ddagger N m=1.5$ for 14 upstream populations of the Broad-Saluda river system and $\mathrm{Nm}=0.6$ for 16 upstream populations of the Catawba-Wateree river system. $\S N m=4.5$ for eight downstream populations of the Great Pee Dee river without the Waccamaw river system and $\mathrm{Nm}=3.4$ for 15 populations of the downstream Waccamaw river system.

orical events and episodic flooding rather than continuous gene flow.

The occurrence of the Georgia and Florida clusters might be caused by historical dispersal or selection. The clusters occupy different latitudes, which are correlated with different environmental factors. In the region of this study, some fish have their latitudinal distribution limited by environmental factors (Getter, 1982; Duggins et al., 1995). Populations of $G$. holbrooki, however, occur all over this region, and there is no report of genetic divergence occurring in the areas where those other fish are absent. According to Avise (1992), intraspecific phylogenies of mtDNA of Gambusia and other taxa from the south-east are more consistent with historical gene flow than with changes in ecological pressures within their range.

In the last five million years, major portions of the Florida peninsula were covered by the ocean on several occasions. During these events, the waters occupied by populations of the Florida cluster partially or completely disappeared. The Cody Scarp, a relict shoreline $30 \mathrm{~m}$ above the present sea level, is evidence that peninsular Florida was reduced to a smaller peninsula and an archipelago (Fig. 1a; Gilbert, 1987). This archipelago was probably a refugium for $G$. holbrooki, which later colonized present-day bodies of water in the peninsula.

The Cody Scarp origin has been placed 3-5 million years ago (Gilbert, 1987) or less than 0.1 million years ago (MacNeil, 1949). A weak divergence between the Georgia and Florida populations was found; this could be the result of isolation for a short period, a long period of strict isolation followed by high gene flow, or a long period of partial isolation with some gene flow. Other species in this region have differentiated more than that found in G. holbrooki (Gilbert, 1987; Avise, 1992). Thus, the differentiation of the Georgia and Florida clusters of populations more probably occurred as in the second or third explanation. Mosquitofish are highly tolerant of a variety of habitats and can disperse through marshy environments more easily than other fishes.

Eastern mosquitofish in southern Georgia and northern Florida have a similar genetic structure to those in the rest of Georgia and the Carolinas. Upstream populations have less genetic variation and more differentiation within and among drainages than downstream populations. Florida populations are also differentiated from those in Georgia. Possible causes of these patterns include historical events, gene flow, selection and genetic drift. Upstream/downstream differences in the effects of either drift or selection are probably larger for drainages with upstream populations in the piedmont than for those with upstream populations in the coastal plain. Gene flow is less among the upstream than among the downstream populations. Isolation of populations in the past and downstream 
gene flow played a key role in shaping the genetic structure of $G$. holbrooki and possibly that of other riverine fishes in the south-east U.S.A.

\section{Acknowledgements}

We appreciate the help of K. Kandl, S. Proctor and B. Webb with the sampling and laboratory work. J. Avise, A. Jones, K. Scribner, C. Stockwell, M. Wooten and two anonymous reviewers provided highly valuable comments. We used the Mantel nonparametric test calculator developed by A. Liedloff. This research was supported by Financial Assistance Award Number DE-FCO9-96SR18546 from the U. S. Department of Energy to the University of Georgia Research Foundation.

\section{References}

ALLENDORF, F. W. 1983. Isolation, gene flow, and genetic differentiation among populations. In: Schonewald-Cox, C. M., Chambers, S. M., MacBryde, B. and Thomas, L. (eds) Genetics and Conservation, pp. 51-65. The Benjamin/Cummings Publishing Company, Menlo Park, CA.

AVISE, J. C. 1992. Molecular population structure and the biogeographic history of a regional fauna: a case history with lessons for conservation biology. Oikos, 63, 62-76.

CONGDON, B. C. 1995. Unidirectional gene flow and maintenance of genetic diversity in mosquitofish Gambusia holbrooki (Teleostei: Poeciliidae). Copeia, 1995, $162-172$.

CROW, J. F. AND AOK1, K. 1984. Group selection for a polygenic behavioral trait: estimating the degree of population subdivision. Proc. Natl. Acad. Sci. U.S.A., 81, 6073-6077.

DUGGins, C. F., JR, F. D., KARLin, A. A., MOUSSEAU, T. A. AND RELYEA, K. G. 1995. Analysis of a hybrid zone in Fundulus majalis in a northeastern Florida ecotone. Heredity, 74, 117-128.

GETTER, C. D. 1982. Temperature limitations to the distribution of mangrove mosquitofish in Florida. Florida Scientist, 45, 196-200.

GILBERT, C. R. 1987. Zoogeography of the freshwater fish fauna of southern Georgia and peninsular Florida. Brimleyana, 13, 25-54.

HERNANDEZ, J. D. 1988. Genetic Variation in Eastern Mosquitofish (Gambusia holbrooki Girard) from the Piedmont and Coastal Plain of the Altamaha, BroadSantee and Pee Dee Drainages. M.Sc. Thesis, University of Georgia.

HeRnANDeZ-Martich, J. D. AND SMith, M. H. 1990. Pattern of genetic variation in eastern mosquitofish (Gambusia holbrooki Girard) from the Piedmont and the Coastal Plain of three drainages. Copeia, 1990, 619-630.

HERNANDEZ-MARTICH, J. D., NOVAK, J. M., SMITH, M. H. AND JOHNS, P. E. 1995. Genetic structure of mosquitofish populations in the Altamaha and Ogeechee drainages of Georgia: reporting an undescribed form in the Ocmulgee river. Biochem. Syst. Ecol., 23, 617-625.

L1, C. C. AND HORVITZ, D. G. 1953. Some methods of estimating the inbreeding coefficient. Am. J. Hum. Genet., 5, 107-117.

LYNCH, J. D. 1988. Introduction, establishment and dispersal of western mosquitofish in Nebraska (Actinopterygii: Poeciliidae). Prairie Nat., 20, 203-216.

MACNElL, F. S. 1949. Pleistocene shore lines in Florida and Georgia. Prof. Pap., U.S. Geol. Surv. 221-F, 95-106.

NEl, M. 1977. $F$-statistics and analysis of gene diversity in subdivided populations. Ann. Hum. Genet., 41, 225-233.

RICE, w. R. 1989. Analyzing tables of statistical tests. Evolution, 43, 223-225.

SAS INSTITUTE 1985. SAS User's Guide: Statistics, Version 5 Edition. SAS Institute, Inc., Cary, NC.

SCRIBNER, K. T. AND AVISE, J. C. 1993. Cytonuclear genetic architecture in mosquitofish populations and the possible roles of introgressive hybridization. Mol. Ecol. 2, 139-149.

Shaw, P. W., CaRvalho, G. R., MagurRan, A. E. AND SEGHERS, B. H. 1994. Factors affecting the distribution of genetic variability in the guppy (Poecilia reticulata). $J$. Fish. Biol., 45, 875-888.

Slatkin, M. 1985. Gene flow in natural populations. Ann. Rev. Ecol. Syst., 16, 393-430.

SMITH, M. W., SMITH, M. H. AND CHESSER, R. K. 1983. Biochemical genetics of mosquitofish. I. Environmental correlates, and temporal and spatial heterogeneity of allele frequencies within a river drainage. Copeia, 1983, 182-193.

SMITH, M. H., SCRIBNER, K. T., HERNANDEZ, J. D. AND wooten, M. C. 1989. Demographic, spatial, and temporal genetic variation in Gambusia. In: Meffe, G. K. and Snelson, F. F. (eds) Ecology and Evolution of Livebearing Fishes (Poeciliidae), pp. 235-257. PrenticeHall, Englewood Cliffs, NJ.

SNEATH, P. H. A. AND SOKAL, R. R. 1973. Numerical Taxonomy. W. H. Freeman \& Co., San Francisco, CA.

SOKAL, R. R. AND ROHLF, F. J. 1995. Biometry, 3rd edn. W. H. Freeman, New York.

Swofford, D, R. AND SElander, R. 1989. Biosys-1. $A$ Computer Program for the Analysis of Allelic Variation in Population Genetics and Biochemical Systematics. Release 1.7. University of Illinois, Urbana, IL.

wooton, R. J. 1990. Ecology of Teleost Fishes. Chapman \& Hall, New York.

WORKMAN, P. L. AND NisWANDER, J. D. 1970. Population studies on southwestern Indian tribes. II. Local genetic differentiation in the Papago. Am. J. Hum. Genet., 22, 24-49.

WRight, s. 1978. Evolution and the Genetics of Populations, vol. 4, Variability within and among Natural Populations. University of Chicago Press, Chicago, IL.

wright, s. 1988. Surfaces of selective value revisited. $\mathrm{Am}$. Nat., 131, 115-123. 